\title{
MOTA, Lúcio Tadeu. As guerras dos indios Kaingang. A História épica dos índios Kaingang no Paraná (1769-1924). $2^{\mathrm{a}}$ ed revisada e ampliada. Maringá: EDUEM, 2009. 301 p.
}

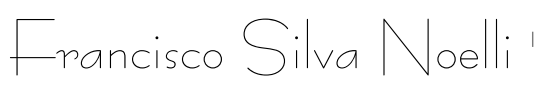

A segunda edição revisada e ampliada deste livro é muito bem-vinda. Sua trajetória começou em 1992, quando foi apresentado e defendido como dissertação de mestrado. Em 1994, foi modificado e preparado para edição, sendo um dos primeiros títulos publicados pela EDUEM, Editora da Universidade Estadual de Maringá, no Paraná. Após dezesseis anos, é possivel dizer que se tornou uma obra de referência de história indígena no Brasil, sobretudo dos Kaingang e da Região Sul do país. Foi o ponto de partida para um amplo projeto de história regional, tendo o Paraná como espaço principal e uma série de temas desenvolvidos posteriormente por Lúcio Tadeu Mota, como a tese de doutorado $O$ aço, a cruz e a terra: indios e brancos no Paraná provincial (1853-1889), defendida em 1998; e os livros: As colônias indigenas no Paraná Provincial (2000) e Os Kaingang do vale do rio Ivai-PR: História e relações interculturais (2008), co-autoria com Éder Novak; e vários livros e artigos sobre a história dos Kaingang e outros povos indigenas, sem contar as publicações dos seus alunos

\footnotetext{
${ }^{1}$ Arqueólogo e Historiador. Prof. aposentado do Departamento de Fundamentos da Educação. Pesquisador do Programa Interdisciplinar de Estudos de Populações, Universidade Estadual de Maringá 
e parceiros de pesquisa. Foram duas prolificas décadas e um exemplo bem sucedido de interiorização da pesquisa, com a participação de Mota na criação do Programa Interdisciplinar de Estudos de Populações da Universidade Estadual de Maringá, em 1997.

Além de analisar um período de 163 anos, As guerras dos indios Kaingang estabelece as linhas gerais para uma história dos Kaingang, sobre suas relações interculturais e alguns dos seus principais líderes. Também mostra possibilidades na ampliação de temas mais comuns da historiografia paranaense, sobretudo na atualização teórica e metodológica de caráter multidisciplinar. Um aspecto decisivo da abordagem desenvolvida é a crítica à historiografia hegemônica produzida no Paraná até o início dos anos 1990, que defendia teses anacrônicas sobre um "vazio demográfico" anterior à presença européia. Sua crítica foi construída a partir de uma farta documentação obtida em fontes publicadas e inéditas, desmistificando uma construção "arquitetada e divulgada" pelos intelectuais paranaenses.

O principal mérito do livro está no levantamento de dados e na sua articulação, a partir de uma perspectiva póscolonial, dedicada a transformar os Kaingang em sujeitos capazes de defender sua autodeterminação nos diversos embates e contatos com os "brancos". Mota conseguiu alterar um padrão historiográfico que se pautou por omitir, sabotar e diminuir o papel das sociedades indígenas na formação das sociedades paranaenses desde o período colonial até as primeiras décadas da República.

A parte 1 analisa as principais idéias de historiadores, geógrafos e sociólogos, debatendo as noções de vazio demográfico, terra de ninguém e terras devolutas. O autor analisa o impacto dessas perspectivas nos livros didáticos e na obras que cantaram a apologia à colonização regional, a partir do século 19.

A parte 2 trata das populações indígenas no Paraná, descrevendo suas principais caracteristicas e delimitando seus territórios. Constitui uma das descrições mais completas dos territórios Kaingang, sendo aperfeiçoada e ampliada 
nas pesquisas posteriores do autor. Resume os principais elementos das várias estratégias Estatais estabelecidas para o tratamento político e fundiário dos Kaingang, que foram da guerra à diplomacia, mas ao fim e ao cabo, acabaram por submeter os direitos e a autodeterminação indígena aos interesses dos agentes do Estado, ao confinamento em verdadeiros campos de concentração e ao descaso com os direitos mais básicos da cidadania. Além disso, foram acrescentados mais dados de arqueologia, ampliando e atualizando o texto em relação à primeira edição.

A parte 3 apresenta detalhes sobre os Kaingang, centrando-se em aspectos mais tradicionais da etnografia, sobretudo dos equipamentos e táticas usados para resistir aos enfrentamentos bélicos com as forças coloniais. Mostra as principais guerras e a resistência às tentativas de desterritorialização e confinamento, tentadas pelos diversos representantes do poder público desde 1769 até o período republicano. Também apresenta as estratégias não militares de resistência e uma lista de caciques, descrevendo suas ações em relação aos "brancos".

É um livro importante que merece ser lido e debatido, pois apresenta vários temas que devem ser mais pesquisados e desenvolvidos sobre a formação da sociedade e do território do Paraná. É possivel declarar que, em termos de ruptura com as perspectivas coloniais da historiografia paranaense, este trabalho é um divisor de águas e a abertura para o caminho da história indígena. Há vinte anos Lúcio Tadeu Mota trouxe uma novidade científica e politica. Novidade, por que refletia o papel efetivo dos Kaingang na história paranaense, com uma abordagem ainda hoje pouco usual no estado. Política, por que considerou os Kaingang como sujeitos reais do passado e do presente do Paraná, dignos de serem vistos e tratados como cidadãos.

Recebido:05/09/2010

Aprovado:15/10/2010 